\title{
Effect of impregnation of La0.85Sr0.15MnO3/Yttria Stabilized Zirconia Solid Oxide Fuel Cell cathodes with La0.85Sr0.15MnO3 or Al2O3 nano-particles
}

\author{
Kammer Hansen, Kent; Wandel, Marie; Liu, Yi-Lin; Mogensen, Mogens Bjerg
}

Published in:

Electrochimica Acta

Link to article, DOI:

10.1016/j.electacta.2010.03.017

Publication date:

2010

Link back to DTU Orbit

Citation (APA):

Kammer Hansen, K., Wandel, M., Liu, Y-L., \& Mogensen, M. B. (2010). Effect of impregnation of

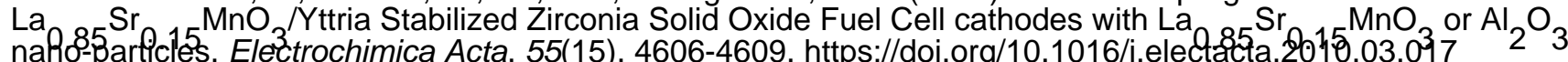

\section{General rights}

Copyright and moral rights for the publications made accessible in the public portal are retained by the authors and/or other copyright owners and it is a condition of accessing publications that users recognise and abide by the legal requirements associated with these rights.

- Users may download and print one copy of any publication from the public portal for the purpose of private study or research.

- You may not further distribute the material or use it for any profit-making activity or commercial gain

- You may freely distribute the URL identifying the publication in the public portal 
Effect of impregnation of $\mathrm{La}_{0.85} \mathrm{Sr}_{0.15} \mathrm{MnO}_{3} /$ Yttria Stabilized Zirconia Solid Oxide Fuel Cell cathodes with $\mathrm{La}_{0.85} \mathrm{Sr}_{0.15} \mathrm{MnO}_{3}$ or $\mathrm{Al}_{2} \mathrm{O}_{3}$ nano-particles

\author{
K. Kammer Hansen ${ }^{1}$, M. Wandel, Y.-L. Liu \& M. Mogensen \\ Fuel Cells and Solid State Chemistry Division \\ Risø National Laboratory for Sustainable Energy \\ Technical University of Denmark \\ DK-4000 Roskilde, Denmark
}

\begin{abstract}
Strontium substituted lanthanum manganite and yttria stabilized zirconia solid oxide fuel cell composite electrodes were impregnated with nano-particles of strontium substituted lanthanum manganite or alumina. A clear positive effect was observed on low performing electrodes and on good performing electrodes if the temperature was kept low after the impregnation with strontium substituted lanthanum manganite. On good performing electrodes the effect disappeared on heating. Alumina nano-particles had a detrimental effect on the activity of the strontium substituted lanthanum manganite based electrodes.
\end{abstract}

1. Introduction: The solid oxide fuel cell (SOFC) converts chemical energy directly into heat and electricity at high temperature [1]. One main obstacle that must be overcome if the SOFC is to be commercialized is the high opration temperature, i.e. a significant lowering of the operation temperature from ca. $800{ }^{\circ} \mathrm{C}$ to $600{ }^{\circ} \mathrm{C}$ is necessary [2]. In order to do this the electrodes has to be improved. Impregnation of state-of the-art composite electrodes of strontium substituted lanthanum manganite

\footnotetext{
${ }^{1}$ Corresponding author. e-mail: kkha@risoe.dtu.dk
} 
and yttria stabilized zirconia (LSM/YSZ) composite SOFC cathodes with nanoparticles of various composition has proven effective in decreasing the polarisation resistance of SOFC electrodes in general $[3,4]$. The positive effect of several types of nano-particles with quite different chemical compositions raised the questions: 1) will there be a positive effect of impregnation of all types of nano-particles? 2) Is the effect of impregnated nano-particles dependent on the electrode structure? These questions have, to our best knowledge not been addressed in the open literature. Thus, in an attempt to address these questions LSM/YSZ cathodes were impregnated with nano-particles of $\left(\mathrm{La}_{0.85} \mathrm{Sr}_{0.15} \mathrm{MnO}_{3+\delta}\right.$ (LSM15) and $\mathrm{Al}_{2} \mathrm{O}_{3}$, respectively. Two different types of LSM/YSZ electrodes, an optimized (screen printed) and a nonoptimized (slurry sprayed), were impregnated with LSM15 in order to investigate the effect of the backbone structure on the activity of the impregnated electrodes. Impregnation of LSM-based cathodes has been tried before and a positive effect has been shown when impregnating with cobalt oxide as well as ceria based materials [68]. However, cobalt-based perovskites are not stable together with the commonly used YSZ electrolyte [9].

2. Experimental: Symmetric cells with LSM/YSZ SOFC cathodes were prepared by either slurry spraying (SS) or screen printing (SP) on both sides of pre-sintered, approximately $200 \mu \mathrm{m}$ thick, in-house fabricated YSZ tape using procedures published elsewhere [6-8]. After sintering the cells were cut into smaller cells with the approximately dimensions $4 * 4 \mathrm{~mm}^{2}$. The impregnation with LSM15 nano-particles was done as follows: An aqueous solution of La-, Sr- and Mn-nitrates in the appropriate ratio was prepared. For impregnation with $\mathrm{Al}$ a solution of $\mathrm{Al}\left(\mathrm{NO}_{3}\right)_{3}$ was also prepared. The nitrates used were $\mathrm{La}\left(\mathrm{NO}_{3}\right)_{3} \cdot 6 \mathrm{H}_{2} \mathrm{O}$ (Alfa Aesar, 99.9\%), $\mathrm{Sr}\left(\mathrm{NO}_{3}\right)_{2}$ 
(Alfa Aesar, 99\%), $\mathrm{Mn}\left(\mathrm{NO}_{3}\right)_{2} \bullet 4 \mathrm{H}_{2} \mathrm{O}$ (Alfa Aesar, 98\%) and $\mathrm{Al}\left(\mathrm{NO}_{3}\right)_{3} \bullet 9 \mathrm{H}_{2} \mathrm{O}$ (Riedelde Häen, 98.5\%). Triton X100 and Pluronic123 (BASF) were then added to the solutions. The impregnation was vacuum assisted. A current collector layer (ca. 15 $\mu \mathrm{m})$ Pt-paste (Engelhard) was applied onto the electrodes either before impregnation (sintered in air) or after impregnation (sintered in-situ at $800^{\circ} \mathrm{C}$ ). The cells were characterized with electrochemical impedance spectroscopy (EIS) in air. All EIS measurements were carried out at open circut voltage (OCV) using a Solartron 1260. The spectra were recorded from $1 \mathrm{MHz}$ to $0.05 \mathrm{~Hz}$ with five points measured at each decade. An amplitude of $24 \mathrm{mV}$ was used throughout. The measurements were done on two cells of each type of cell. The fitting of the impedance data were done using the PC-DOS program 'equivcrt' by B.A. Boukamp [10]. In general the spectra were fitted with as few (RQ) elements as possible while still obtaining a solid fit. $\mathrm{R}$ is a resistance and $\mathrm{Q}$ is a constant phase element with the admittance:

$$
\text { (1) } \quad Y=Y_{0}\left(j \omega / \omega_{0}\right)^{n} \text {, }
$$

where $Y_{0}$ is a constant, $\omega$ is the cyclic frequency, and $n$ is an exponent. $Y_{0}$ and $n$ is found from the fitting.

The slurry sprayed cells were heated to $800^{\circ} \mathrm{C}$ in air before the electrochemical characterization. The screen printed cells were heated to either $800^{\circ} \mathrm{C}$ or to $600^{\circ} \mathrm{C}$ in air before the electrochemical characterization.

Micrographs of the symmetrical cells were recorded on a Zeiss Supra 35 scanning electron microscope (SEM) equipped with a field emission gun. 
3. Results: A SEM backscattered micrograph of a screen printed LSM15 unimpregnated symmetrical cell can be found in Figure 1. In Figure 2 a SEM backscattered micrograph of an LSM15 impregnated screen printed symmetrical cell heated to $600^{\circ} \mathrm{C}$ is shown. It is seen that that a larger fraction of small particles are present for the impregnated electrode than for the un-impregnated electrode. Results from the EIS measurements can be found in Table 1 and Figure 3. In general the EIS spectra consist of three $\operatorname{arcs}$ at $600^{\circ} \mathrm{C}$, and two to three arcs at higher temperature, see also Table 2 to 4 . As can been seen in Table 1 a clear effect is observed when impregnating LSM/YSZ electrodes with LSM15. The effect is largest on the cells prepared by slurry spraying. Arrhenius plots of the different electrodes are shown in Figure 4 to 6 , with and without impregnation with LSM. It is seen that for the slurry sprayed electrodes the apparent activation energy is almost unaffected by the impregnation, see Figure 4. For the screen printed electrodes heated to $800^{\circ} \mathrm{C}$ no effect is observed upon impregnation with LSM, see Figure 5. In Figure 6 it is seen that the screen printed electrodes heated to $600^{\circ} \mathrm{C}$ have a higher activity after impregnation. The effect of impregnation is lost when the electrodes is heated to $700^{\circ} \mathrm{C}$. Apparent activation energies for some of the electrodes are given in Table 5.

4. Discussion: When a cell made by slurry spraying is impregnated with LSM15 a large improvement of the ASR is achieved. As can be seen by consulting Table 3 the magnitude of all three arcs is decreased when impregnating with LSM15. The low frequency arc is the one that decreases the most. This arc is normally attributed to a slow oxygen-exchange reaction at the surface of the electrode [11]. This arc is probably minimized due to a larger surface area of the LSM in the electrodes due to the small particles formed as a result of the impregnation with LSM15, see Figure 2. 
The medium frequency arcs are probably due to transport across the LSM/YSZ surface and through the bulk of the YSZ of the composite [12]. This arc is also affected by the LSM15 impregnation. The high frequency arc is known to be due to transport of oxide ions across the electrode/electrolyte interface [11, 12]. This arc is also affected by the impregnation with LSM15. The near-equivalent capacity of this arc can be calculated using equation (2) below [13]:

$$
\mathrm{C}_{\omega}=\mathrm{R}^{(1-\mathrm{n}) / \mathrm{n}} Y_{0}^{1 / n}
$$

The near-equivalent capacity of this arc is around $0.5 \mu \mathrm{F} / \mathrm{cm}^{2}$ strongly suggesting that this arc is due to a double layer capacitance [14]. Furthermore, the absolute ASR values of the slurry sprayed LSM/YSZ cathodes are higher compared to the screen printed LSM/YSZ cathodes even after the impregnation with LSM15. This shows that the backbone structure also is important in order to achieve a high activity of the electrodes. That the effect of impregnating the un-optimized backbone is larger than the effect of impregnating the optimized backbone could be due to the following. In the optimized backbone the LSM and YSZ particles are better dispersed than in the un-optimized backbone. When impregnating with LSM the LSM nano-particles are dispersed over the backbone structure. The effect of this will then be larger on the unoptimized backbone structure than on the optimized backbone structure, where the LSM and YSZ particles already are well dispersed. However, an effect of impregnating the screen printed electrodes with LSM15 is seen on the electrodes that have not been at high temperature, see Table 1 . The effect is largest on the low frequency arc, showing that the impregnated LSM15 affects the slow oxygenexchange reaction at the surface of the electrode in a positive manner. The catalytic 
properties of the impregnated LSM15 are destroyed when the screen printed electrodes are heated to $800^{\circ} \mathrm{C}$, probably due to coarsening of the impregnated LSM15 particles.

From the apparent activation energies given in Table 2, it is seen that the apparent activation energy is almost unaffected by the impregnation with LSM. This might be taken as an indication of that the mechanism of the reduction of oxygen on LSM/YSZ electrodes is unaffected by the impregnation with LSM, that is the rate of the reduction of oxygen is changed but the mechanism is the same.

When impregnating with $\mathrm{Al}_{2} \mathrm{O}_{3}$ a detrimental effect was observed, see Table 3. There can be several reasons for this. Either the alumina reacts with the LSM lowering the activity of the LSM phase as it has been observed for ferrites [15], or the alumina particles covers the catalytic active sites on the LSM particles. It should, however, be noted that impregnation with un-doped ceria also enhances the activity of SOFC electrodes [16]. The electro-catalytic activity of the surface of ceria can be determined as the oxygen surface exchange coefficient. From the oxygen surface exchange coefficient the ASR of ceria can be determined to approximately $100 \Omega \mathrm{cm}^{2}$ at $600{ }^{\circ} \mathrm{C}$ [16]. Furthermore, un-doped ceria have both a very low electronic and ionic conductivity in air. The electro-catalytic activity of un-doped ceria in itself is therefore very low, just like alumina. This point in the direction that other effect than just the catalytic effect of the impregnated materials plays a role in determining the activity of the impregnated electrode. It could be that the nano-particles (by reaction with the surface segregations [17]) alter the surface properties (the impurities) of the triple phase boundary, ceria in a positive way and alumina in a negative way. 
5. Conclusions: Impregnation with LSM nano-particles leads to improvement of the LSM/YSZ composite cathode. The effect is largest on low performing LSM/YSZ cathodes or on LSM/YSZ cathodes that has not been at high temperature $\left(800^{\circ} \mathrm{C}\right)$ after the impregnation with LSM. Impregnation with alumina leads to a lowering of the electrochemical performance of the LSM/YSZ electrodes.

Acknowledgements: The technical staff at the Fuel Cells and Solid State Chemistry Division is thanked for help with preparation of the cells. Dr. P. Blennow is thanked for assistance with the impregnation. Financial support from Energinet.dk through PSO-R\&D-project no. 2006-1-6493 is gratefully acknowledged.

\section{References:}

[1] N.Q. Minh, T. Takahashi, 'Science and technology of ceramic fuel cells', Elsevier Science B.V., 1995

[2] N.Q. Minh, J. Am. Ceram. Soc. 76 (1993) 563

[3] S. P. Jiang, Materials Science and Engineering A 418 (2006) 199

[4] J.M. Vohs, R.J. Gorte, Adv. Mat. 21 (2009) 943

[5] K. Yamahara, C.P. Jacobsen, S.J. Visco, X.-F. Zhang, L.C. De Jonghe, Solid State Ionics $176(2005) 275$

[6] C. Lu, T.Z. Sholklapper, C.P. Jacobsen, S.J. Visco, L.C. De Jonghe, J. Electrochem. Soc. 153 (2006) A1115

[7] T.Z. Sholklapper, V. Radmilovic, C.P. Jacobsen, S.J. Visco, L.C. De Jonghe, Electrochem. Solid-State Letters 10 (2007) B74

[8] M. Søgaard, T.Z. Sholklapper, M. Wandel, L.C. De Jonghe, M. Mogensen, Infiltration of SOFC cathodes. In: Proceedings (on CD-ROM). 8th European 
solid oxide fuel cell forum, Lucerne (CH), 30 Jun - 4 Jul 2008. (European solid oxide fuel cell forum, 2008)

[9] Y. Liu, W. Rauch, S. Zha, M. Liu, Solid State Ionics 166 (2004) 261

[10] B.A. Boukamp, Solid State Ionics 20 (1986) 31

[11] E. Siebert, A. Hammouche, M. Kleitz, Electrochim. Acta 40 (1995) 1741

[12] M.J. Jørgensen, M. Mogensen, J. Electrochem. Soc. 148 (2001) A433

[13] T. Jacobsen, B. Zachau-Christiansen, L. Bay, S. Skaarup, in: F.W. Poulsen et al. (Ed.), Proceedings of the $17^{\text {th }}$ International Symposium on Materials Science; High Temperature Electrochemistry: Ceramics and Metals, Roskilde, Denmark, (1996), pp. 29

[14] N.L. Robertson, J.N. Michaels, J. Electrochem. Soc. 138 (1991) 1494

[15] G.W. Coffey, J. Hardy, L.R. Pedersen, P.C. Rieke, E.C. Thomsen, M. Walpole, Solid State Ionics 158 (2003) 1

[16] M. Mogensen, M. Søgaard, P. Blennow, K. Kammer Hansen, The Action of SOFC nano-particles. In: Proceedings (on CD-ROM). 8th European solid oxide fuel cell forum, Lucerne (CH), 30 Jun - 4 Jul 2008. (European solid oxide fuel cell forum, 2008)

[17] M. Mogensen, K.V. Hansen, in: Wolf Vielstich, Harumi Yokokawa, Hubert A. Gasteiger (Ed.), Handbook of Fuel Cells - Fundamentals, Technology and Applications: Advances in Electocatalysis, Materials, Diagnostics and Durability, vol. 5, John Wiley \& Sons, (2009), p. 543. 
Table captions

Table 1. Total ASR for the six electrode types characterized by EIS at three temperatures in air. The ASR values are given in $\Omega \mathrm{cm}^{2}$. The six electrodes are either slurry sprayed or screen printed electrodes with and without LSM impregnation. The impregnated screen printed cells has been heated at either 600 or $800^{\circ} \mathrm{C}$ before the measurements.

Table 2. ASR of the individual arcs for the slurry sprayed electrodes (SS) at $600^{\circ} \mathrm{C}$ in air. Arc 1 is the high frequency arc, arc 2 the medium frequencies arc and $\operatorname{arc} 3$ is the low frequency arc. ASR data is given in $\Omega \mathrm{cm}^{2}$.

Table 3. ASR of the individual arcs at $600^{\circ} \mathrm{C}$ in air for the screen printed electrodes (SP) which had been pre-heated to $800^{\circ} \mathrm{C}$. Arc 1 is the high frequency arc, arc 2 the medium frequencies arc and arc 3 is the low frequency arc. ASR data is given in $\Omega \mathrm{cm}^{2}$.

Table 4. ASR of the individual arcs at $600^{\circ} \mathrm{C}$ in air for the screen printed electrodes (SP) which had been pre-heated to $600^{\circ} \mathrm{C}$. Arc 1 is the high frequency arc, 3 the medium frequencies arcs and arc 3 is the low frequency arc. ASR data is given in $\Omega \mathrm{cm}^{2}$.

Table 5. The apparent activation energies for the total ASR for four of the electrodes in air. 
Tables

Table 1

\begin{tabular}{|c|c|c|c|c|c|c|}
\hline Electrode type & \multicolumn{2}{|c|}{ SS } & \multicolumn{2}{c|}{ SP $\left(800^{\circ} \mathrm{C}\right)$} & \multicolumn{2}{c|}{ SP $\left(600^{\circ} \mathrm{C}\right)$} \\
\hline Temperature & -LSM & + LSM & -LSM & + LSM & -LSM & + LSM \\
\hline $600^{\circ} \mathrm{C}$ & 7.13 & 4.10 & 3.14 & 2.82 & 3.14 & 0.93 \\
\hline $700^{\circ} \mathrm{C}$ & 1.32 & 0.86 & 0.35 & 0.33 & 0.35 & 0.36 \\
\hline $800^{\circ} \mathrm{C}$ & 0.35 & 0.19 & 0.094 & 0.082 & 0.094 & 0.072 \\
\hline
\end{tabular}

Table 2

\begin{tabular}{|c|c|c|c|c|c|c|}
\hline $\mathrm{T}=600^{\circ} \mathrm{C}$ & \multicolumn{2}{|c|}{-LSM } & \multicolumn{2}{|c|}{$+\mathrm{LSM}$} & \multicolumn{2}{c|}{$+\mathrm{Al}_{2} \mathrm{O}_{3}$} \\
\hline $\mathrm{Arc}$ & $\mathrm{ASR}$ & $\mathrm{n}$ & ASR & $\mathrm{n}$ & $\mathrm{ASR}$ & $\mathrm{n}$ \\
\hline 1 & $3.02 \pm 0.1$ & 0.35 & $1.70 \pm 0.1$ & 0.35 & $2.19 \pm 0.1$ & 0.40 \\
\hline 2 & $2.76 \pm 0.1$ & 0.76 & $1.56 \pm 0.3$ & 0.80 & $4.08 \pm 0.2$ & 0.66 \\
\hline 3 & $2.16 \pm 0.6$ & 0.98 & $1.68 \pm 0.3$ & 0.98 & $5.69 \pm 0.5$ & 0.95 \\
\hline
\end{tabular}

Table 3

\begin{tabular}{|c|c|c|c|c|}
\hline Arc & \multicolumn{2}{|c|}{-LSM } & \multicolumn{2}{c|}{ +LSM } \\
\hline & ASR & n & ASR & $n$ \\
\hline 1 & $0.56 \pm 0.1$ & 0.70 & $0.57 \pm 0.1$ & 0.66 \\
\hline 2 & $1.11 \pm 0.01$ & 0.44 & $0.69 \pm 0.01$ & 0.47 \\
\hline 3 & $1.47 \pm 0.1$ & 0.91 & $1.56 \pm 0.01$ & 0.93 \\
\hline
\end{tabular}

Table 4

\begin{tabular}{|c|c|c|c|c|}
\hline Arc & \multicolumn{2}{|c|}{-LSM } & \multicolumn{2}{c|}{ +LSM } \\
\hline & ASR & $\mathrm{n}$ & ASR & $\mathrm{n}$ \\
\hline 1 & $0.56 \pm 0.1$ & 0.70 & $0.26 \pm 0.03$ & 0.75 \\
\hline 2 & $1.11 \pm 0.01$ & 0.44 & $0.28 \pm 0.03$ & 0.56 \\
\hline 3 & $1.47 \pm 0.1$ & 0.91 & $0.39 \pm 0.05$ & 0.95 \\
\hline
\end{tabular}

Table 5

\begin{tabular}{|c|c|c|c|c|}
\hline Electrode type & \multicolumn{2}{|c|}{ SS } & \multicolumn{2}{c|}{ SP $\left(800^{\circ} \mathrm{C}\right)$} \\
\hline & -LSM & $+\mathrm{LSM}$ & -LSM & $+\mathrm{LSM}$ \\
\hline $\mathrm{E}_{\mathrm{a}} / \mathrm{KJ} \mathrm{mol}^{-1}$ & $122.4 \pm 0.1$ & $119.3 \pm 0.1$ & $126.0 \pm 0.1$ & $130.1 \pm 0.1$ \\
\hline
\end{tabular}


Figure captions

Figure 1. Fractured cross-section view micrograph of un-impregnated screen printed cathode.

Figure 2. Fractured cross-section view micrograph of LSM impregnated cathode heated treated at $600^{\circ} \mathrm{C}$ in air. Small LSM particles are seen to cover the larger particles.

Figure 3. EIS spectra of the slurry sprayed cells with and without impregnation with $\mathrm{LSM} 15$ at $600^{\circ} \mathrm{C}$ in air.

Figure 4. Arrhenius plots of the slurry sprayed cells in air.

Figure 5. Arrhenius plots of the LSM impregnated screen printed cells heated to $800^{\circ} \mathrm{C}$ before the EIS measurements in air.

Figure 6. Arrhenius plots of the LSM impregnated screen printed cells heated to $600^{\circ} \mathrm{C}$ before the EIS measurements in air. 
Figure 1

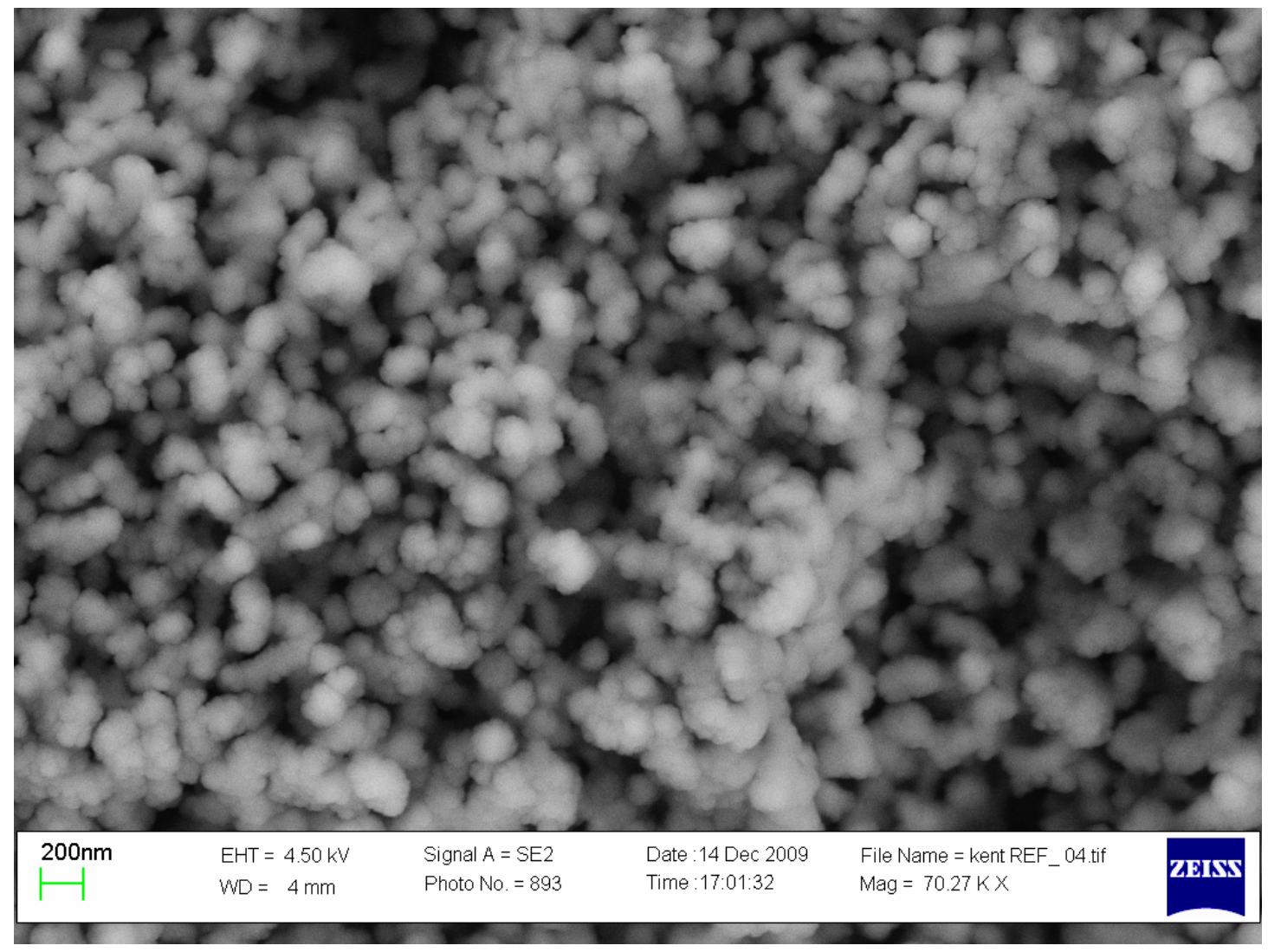


Figure 2.

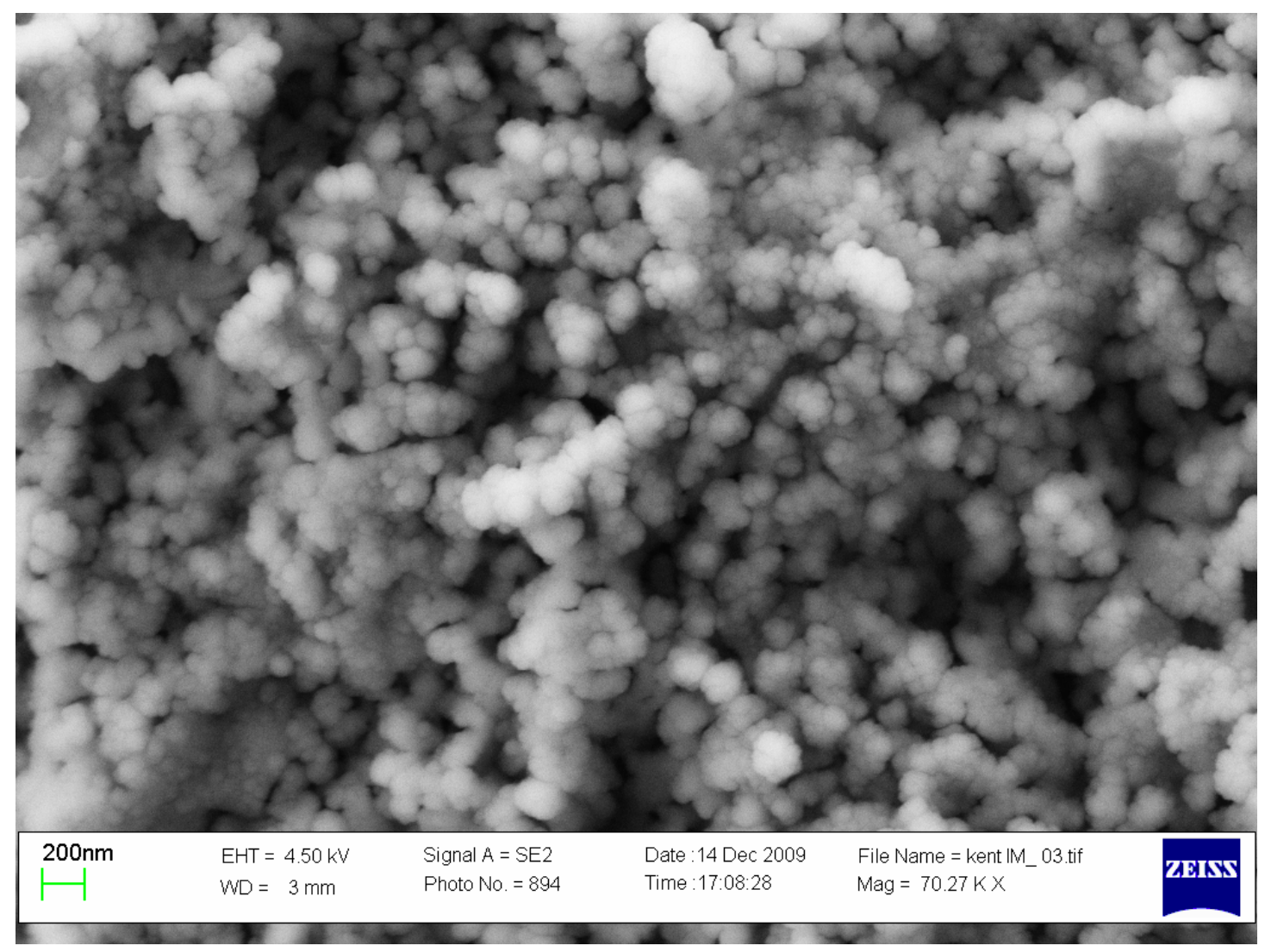


Figure 3

$600^{\circ} \mathrm{C}$ (slurry)

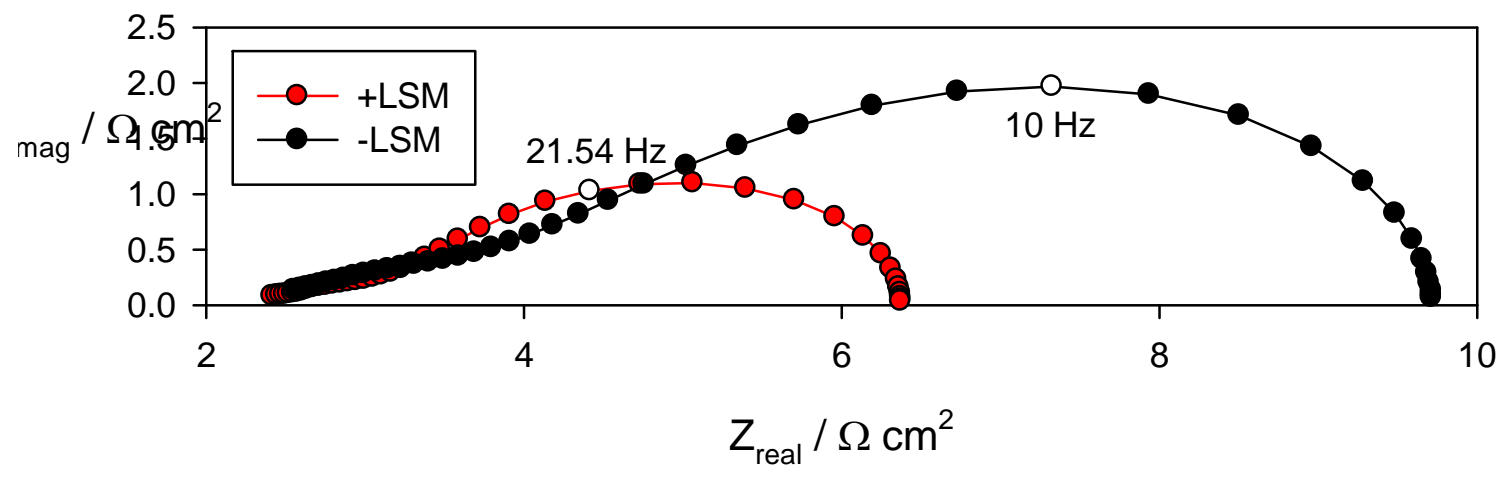


Figure 4.

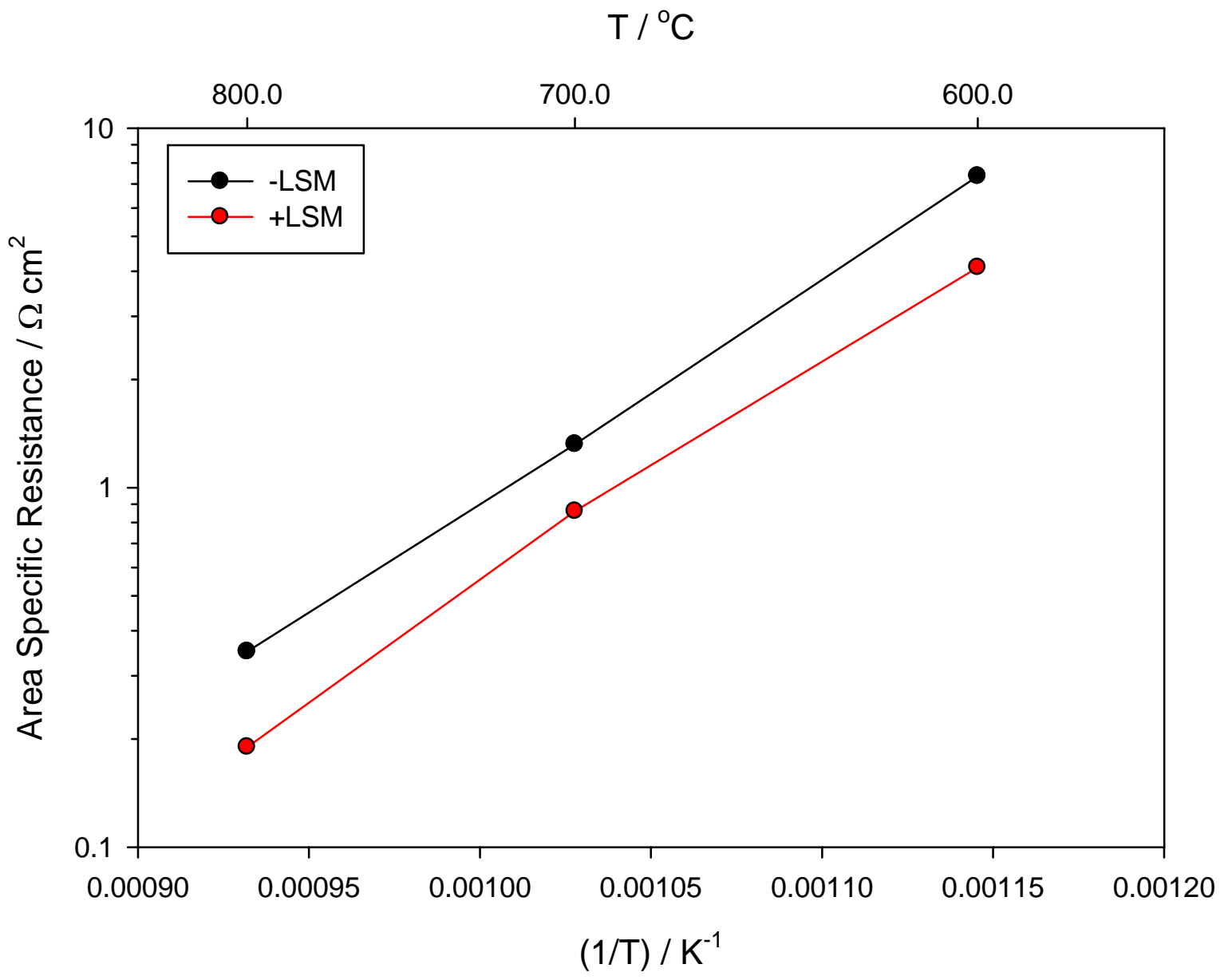


Figure 5

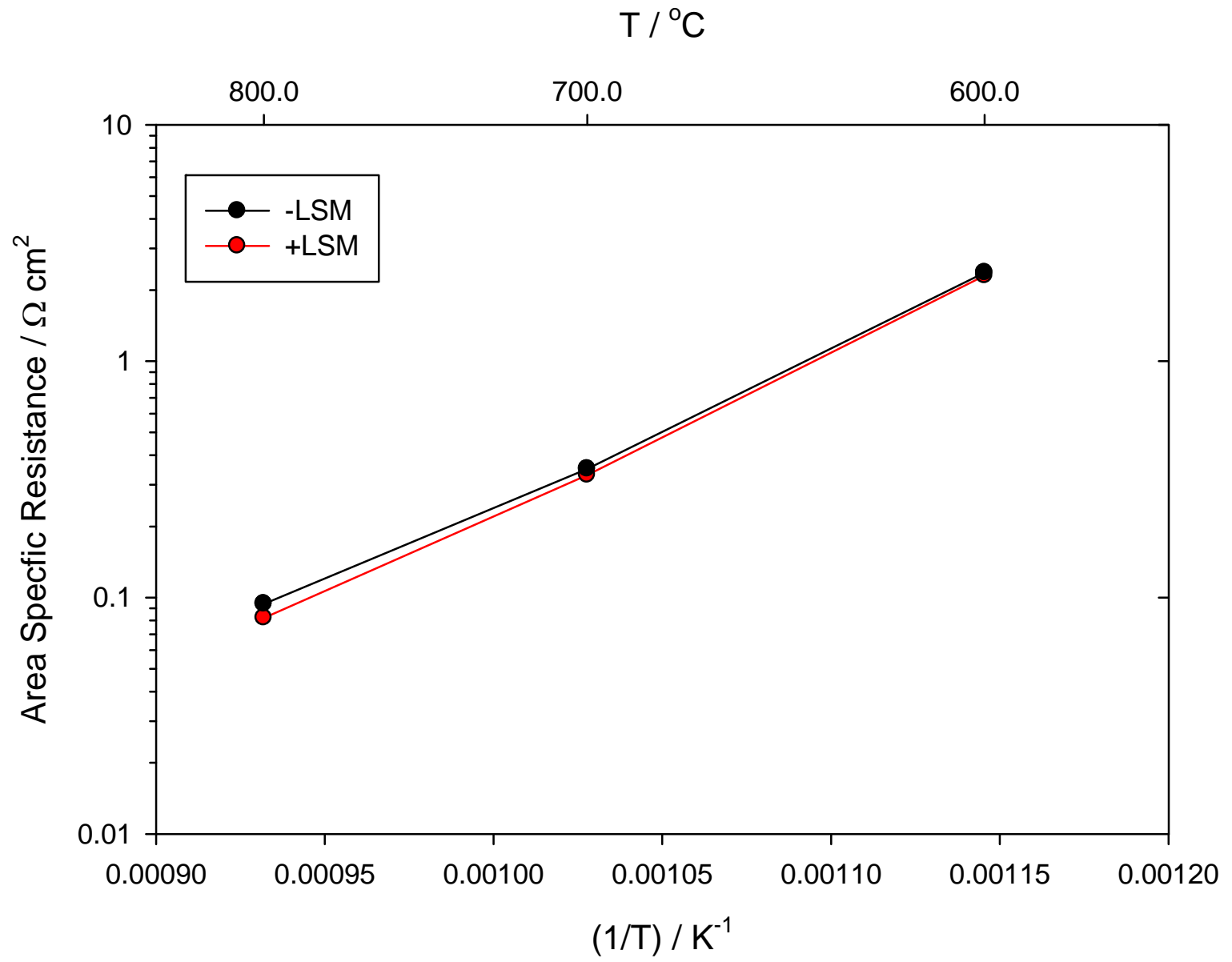


Figure 6.

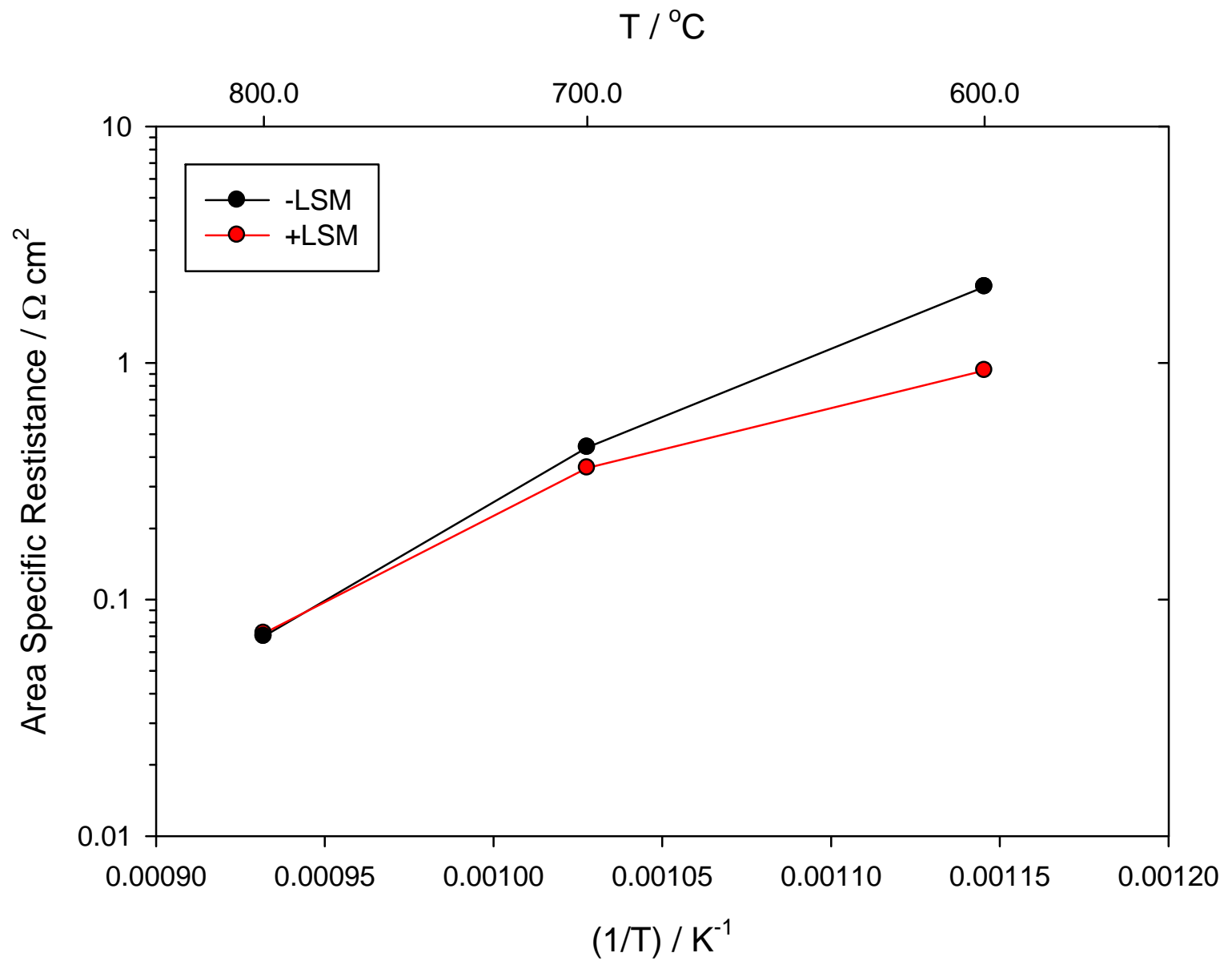

